\title{
D41 報告
}

\section{Acid Leaching of Chalcopyrite Concentrate with Hematite Powder as an Effective Promoter*}

\author{
by Ezequiel Cruz SANCHEZ ${ }^{1}$, Yoshiaki UMETSU ${ }^{2}$ and Fumio SAITO $^{2}$
}

\begin{abstract}
Leaching of chalcopyrite concentrate having specific surface area of about $3 \mathrm{~m}^{2} / \mathrm{g}$ in $0.5 \mathrm{~mol} / \mathrm{dm}^{3} \mathrm{HCl}$ solution was conducted at $333 \mathrm{~K}$ using hematite $\left(\mathrm{Fe}_{2} \mathrm{O}_{3}\right)$ and ferric chloride $\left(\mathrm{FeCl}_{3}\right)$ powders, respectively. The leaching of the concentrate with $\mathrm{Fe}_{2} \mathrm{O}_{3}$ powder permits to achieve about $75 \%$ copper extraction within 24 hours, while about $65 \%$ copper is extracted by the leaching with $\mathrm{FeCl}_{3}$ powder. The yield of copper in the leaching with $\mathrm{Fe}_{2} \mathrm{O}_{3}$ powder is twice or more higher than that without the promoters. High copper extraction can be achieved when much of the elemental sulfur is formed on the solid residue after the leaching. Especially, the presence of $\mathrm{Fe}_{2} \mathrm{O}_{3}$ powder gives us the elemental sulfur precipitates more than that of $\mathrm{FeCl}_{3}$ powder. Therefore, $\mathrm{Fe}_{2} \mathrm{O}_{3}$ can be an effective promoter in the leaching of chalcopyrite concentrate using $\mathrm{HCl}$ solution.
\end{abstract}

KEY WORDS : Chalcopyrite, Hematite, Ferric Chloride, Acid Leaching, Elemental Sulfur, Copper Extraction

\section{Introduction}

It is known that high copper extraction can not be achieved in the leaching of chalcopyrite $\left(\mathrm{CuFeS}_{2}\right)$ concentrate using $\mathrm{HCl}$ solution without any promoters. The reaction of chalcopyrite with the solution is expressed by Eq.(1):

$$
\begin{aligned}
& \mathrm{CuFeS}_{2}(\mathrm{~s})+4 \mathrm{HCl}(\mathrm{aq}) \rightarrow \mathrm{CuCl}_{2}(\mathrm{aq})+\mathrm{FeCl}_{2}(\mathrm{aq}) \\
& +2 \mathrm{H}_{2} \mathrm{~S}(\mathrm{aq})
\end{aligned}
$$

In this equation, when $\mathrm{H}_{2} \mathrm{~S}(\mathrm{aq})$ in the solution is oxidized under mild oxidation state, elemental sulfur forms a layer on the surface of chalcopyrite ${ }^{1)}$. The elemental sulfur layer is considered to be a sort of barrier for the dissolution of the concentrate into the solution, resulting in low copper extraction. To overcome this difficulty, mainly three processes have been developed in the hydrometallurgical treatment of chalcopyrite: One is the ferric chloride $\left(\mathrm{FeCl}_{3}\right)$ process, the second the cupric chloride $\left(\mathrm{CuCl}_{2}\right)$ one, and the third the sulfate process using $\mathrm{Fe}\left(\mathrm{SO}_{4}\right)_{1.5}{ }^{2}$. The kinetics of oxidative leaching of chalcopyrite in an acidic aqueous solution of such chlorides and sulfate media from mechanistic, electrochemical and morphological points of view have been studied since $1985^{3)}{ }^{-6)}$. In the meantime, these processes have several advantages related to sulfur control, metal purification and process economic ${ }^{7)}$. However, they need a lot of media, and the severe leaching conditions are required to achieve high copper yield of extraction. Under such circumstances, an alternative and novel process would be strongly expected in the field of chalcopyrite processing. The authors have introduced that hematite $\left(\mathrm{Fe}_{2} \mathrm{O}_{3}\right)$ is one of the effective promoters in acid

* Received September 25, 1996: accepted for publication June 27, 1997 1,2. Institute for Advanced Materials Processing, Tohoku University, 2-1-1, Katahira, Aoba-ku, Sendai 980, Japan

1. Visiting Scientist, 2. Professor, Dr.

[For correspondence] TEL \& FAX 022-217-5135 (F. Saito, Tohoku Univ.) leaching of chalcopyrite ${ }^{8)}$. However, difference in the extractive characteristics in the leaching with $\mathrm{Fe}_{2} \mathrm{O}_{3}$ and other promoters such as $\mathrm{FeCl}_{3}$ has not been clarified yet.

The main purpose of this paper is to provide information on the difference in the yield of copper in the chalcopyrite leaching using $\mathrm{HCl}$ solution with $\mathrm{Fe}_{2} \mathrm{O}_{3}$ and $\mathrm{FeCl}_{3}$, respectively.

\section{Experimental}

\section{$2 \cdot 1$ Samples}

Chalcopyrite concentrate used in this experiment is supplied by Matsumine Mines, Hanaoka Mining Co. Ltd., Japan. The concentrate is composed mainly of $\mathrm{CuFeS}_{2}(58 \%)$ with impurities such as pyrite $\left(\mathrm{FeS}_{2}: 26 \%\right)$, sphalerite ( $\mathrm{PbS}: 8 \%$ ) and galena $(\mathrm{ZnS})$. The chemical composition of the concentrate is as follows: $\mathrm{Cu}: 19.9 \%, \mathrm{Fe}: 29.8 \%, \mathrm{~S}: 35.1 \%, \mathrm{~Pb}: 4.5 \%$ and $\mathrm{Zn}: 5.2 \%$. Apparent density of the concentrate was measured as $4.37 \mathrm{Mg} / \mathrm{m}^{3}$. The as-received chalcopyrite concentrate contained coarse particles so that it was ground by a ball mill. Then, sieving operation was conducted to prepare the powder passing through $74 \mu \mathrm{m}$ as a starting sample. The specific surface area of the starting sample of the chalcopyrite concentrate was measured as about $3 \mathrm{~m}^{2} / \mathrm{g}$. $\mathrm{Fe}_{2} \mathrm{O}_{3}$ (density : $5.26 \mathrm{Mg}$ $/ \mathrm{m}^{3}$, purity : $99 \%$ ) and $\mathrm{FeCl}_{3}$ (density : $2.80 \mathrm{Mg} / \mathrm{m}^{3}$, purity : 98 $\%)$ powders were used as promoters in the leaching of the chalcopyrite concentrate using $\mathrm{HCl}$ solution. The both oxide and chloride promoters are chemical reagents and their mean diameters were about $0.1 \mu \mathrm{m}$.

\section{$2 \cdot 2$ Experimental procedure}

Three kinds of leaching systems were employed in this work: One is the chalcopyrite concentrate- $\mathrm{HCl}$ solution system without any promoters, the second the chalcopyrite concentrate- $\mathrm{HCl}$ solution system with $\mathrm{Fe}_{2} \mathrm{O}_{3}$ powder and the last one the chalcopyrite concentrate- $\mathrm{HCl}$ solution system 
with $\mathrm{FeCl}_{3}$ powder. In the leaching of the chalcopyrite concentrate alone, four grams of the concentrate sample were dispersed in $250 \mathrm{~m} l$ of $0.5 \mathrm{~mol} / \mathrm{dm}^{3} \mathrm{HCl}$ solution with stirring by a magnetic stirrer. In the case of the mixture of concentrate and $\mathrm{Fe}_{2} \mathrm{O}_{3}$ powders, two kinds of leaching tests were carried out: One is the leaching of the mixture containing $4.0 \mathrm{~g}$ chalcopyrite concentrate and $1.5 \mathrm{~g} \mathrm{Fe}_{2} \mathrm{O}_{3}$ powders by the 250 $\mathrm{m} l \mathrm{HCl}$ solution. Another test is the leaching of the both powders in the $\mathrm{HCl}$ solution, but the two kinds of powders were divided each other by a net in the solution so as to collect them separately after the leaching. In the leaching of the chalcopyrite concentrate with $\mathrm{FeCl}_{3}$ powder, $4.0 \mathrm{~g}$ chalcopyrite concentrate and $3.0 \mathrm{~g} \mathrm{FeCl}_{3}$ powders were put together into the $250 \mathrm{~m} l$ of the $\mathrm{HCl}$ solution with stirring. The reason why the sample weight of $\mathrm{Fe}_{2} \mathrm{O}_{3}$ powder was set at half of the weight of $\mathrm{FeCl}_{3}$ powder is to fit the concentration of $\mathrm{Fe}^{3+}$ in the solution. In all cases, the temperature of the suspension during the leaching was controlled at $333 \mathrm{~K}$, and leaching time was varied from 6 hours to 3-days. After the prescribed leaching time, the mother solution was separated from the solid particles (residues) by filtration. Subsequently, the solution (filtrate) was investigated by an ICP analysis to determine the concentration of the elements dissolved in it. On the other hand, the solid particles and residues before and after the leaching were analyzed by X-ray diffraction (XRD) method to identify their constituent components and phases.

\section{Results and Discussion}

Fig. 1 shows the yield of copper in the leaching of the chalcopyrite concentrate with and without the promoters as a function of leaching time. The warped line (a) denotes the yield in the leaching with $\mathrm{Fe}_{2} \mathrm{O}_{3}$ powder, the line (b) the yield in the leaching with $\mathrm{FeCl}_{3}$ and the line (c) the yield in the leaching without the promoters. From the results, the yield in the leaching without the promoters is found to reach only

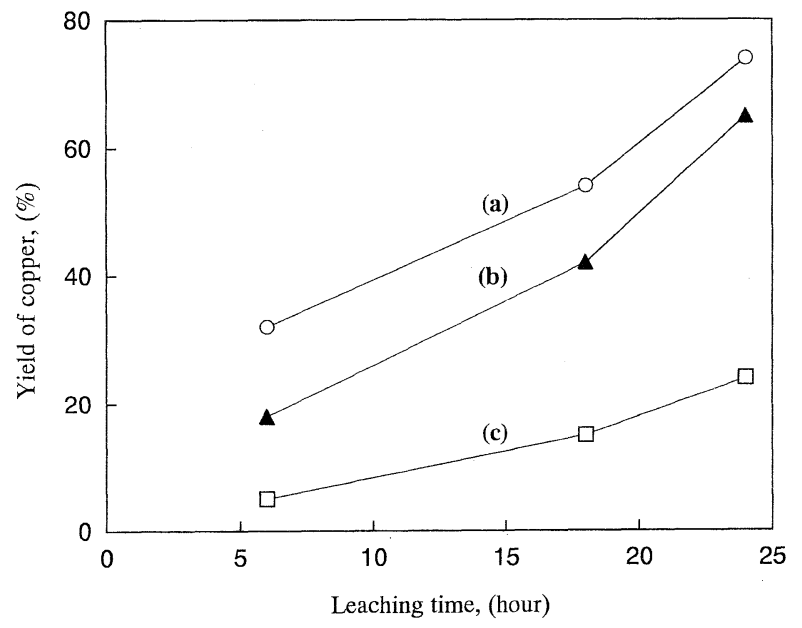

Fig. 1 Yield of copper in the leaching of chalcopyrite concentrate with and without the promoters as a function of leaching time.

(a) chalcopyrite concentrate/ $/ \mathrm{HCl}$ solution $\left.+\mathrm{Fe}_{2} \mathrm{O}_{3}\right)$

(b) chalcopyrite concentrate/ $/ \mathrm{HCl}$ solution $\left.+\mathrm{FeCl}_{3}\right)$

(c) chalcopyrite concentrate/ $\mathrm{HCl}$ solution about $24 \%$ at 24 hours leaching. Furthermore, these values are found to be always lower than the both yield values in the leaching with $\mathrm{Fe}_{2} \mathrm{O}_{3}$ and $\mathrm{FeCl}_{3}$, respectively. Comparing the yield values in the leaching with $\mathrm{Fe}_{2} \mathrm{O}_{3}$ powder with those with $\mathrm{FeCl}_{3}$ powder, the former values are slightly higher than the latter ones. It is therefore found that $\mathrm{Fe}_{2} \mathrm{O}_{3}$ powder is an effective promoter in the leaching of chalcopyrite concentrate using $\mathrm{HCl}$ solution.

Fig. 2 shows the XRD patterns of the solids residues after the 24 hours leaching of the chalcopyrite sample with and without the promoters. That is, the pattern (a) denotes the solid residue after the leaching of the chalcopyrite sample alone, the pattern (b) the solid residue after the leaching with $\mathrm{Fe}_{2} \mathrm{O}_{3}$ powder and the pattern (c) the residue in the leaching with $\mathrm{FeCl}_{3}$ powder. As can be seen from the figure, the peaks of chalcopyrite are found to disappear in the pattern (b), while they still exist in the patterns (a) and (c). This means that most of chalcopyrite dissolves into the $\mathrm{HCl}$ solution within 24 hours when $\mathrm{Fe}_{2} \mathrm{O}_{3}$ powder is present, while chalcopyrite is still remain in the sample in the cases without the promoters and with $\mathrm{FeCl}_{3}$ powder. Moreover, it is clearly observed that the peaks intensity of sulfur in the patterns ( $b$ ) and (c) is significantly higher than that in the pattern (a). In addition, the intensity of sulfur in the pattern (b) is marginally higher than that in the pattern (c). This implies that high copper extraction can be achieved when much of the elemental sulfur is formed after the leaching. Especially, the presence of $\mathrm{Fe}_{2} \mathrm{O}_{3}$ powder leads to promote the dissolution of chalcopyrite, accompanying with the elemental sulfur precipitates more than $\mathrm{FeCl}_{3}$ powder. Majima ${ }^{2)}$ reported that the elemental sulfur layer formed on the surface of chalcopyrite in chloride media such as $\mathrm{FeCl}_{3}-\mathrm{HCl}$ solution system is porous and does not seem to be a barrier to further leaching. However, in the present study, no microscopic observation regarding the elemental sulfur layer formed on the surface of

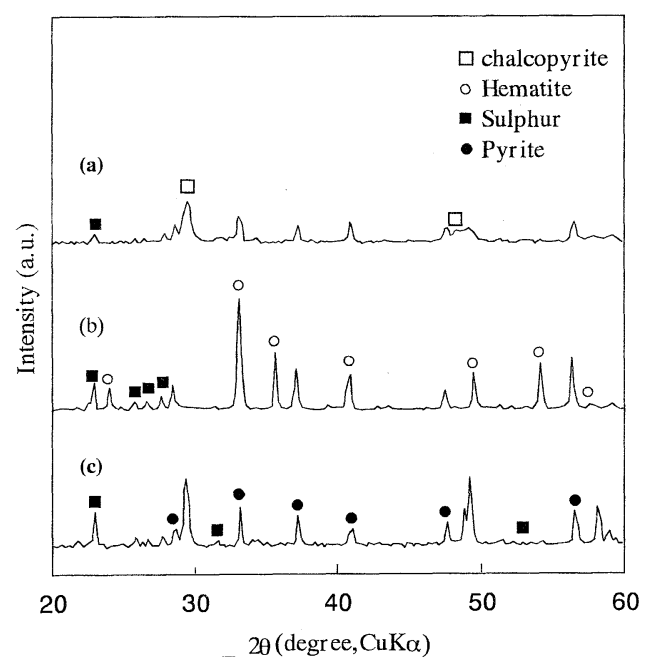

Fig. 2 XRD patterns of the residues after 24-hours leaching of the chalcopyrite concentrate.

(a) without the promoters

(b) with $\mathrm{Fe}_{2} \mathrm{O}_{3}$ powder

(c) with $\mathrm{FeCl}_{3}$ powder 
chalcopyrite was carried out. Therefore, the difference in the elemental sulfur layers when $\mathrm{Fe}_{2} \mathrm{O}_{3}$ and $\mathrm{FeCl}_{3}$ powders were used is still in the state of uncertainly.

Fig. 3 shows the XRD patterns of the residues (a) and (b) after 3-days leaching of the chalcopyrite sample and the $\mathrm{Fe}_{2} \mathrm{O}_{3}$ powder both soaked in the $\mathrm{HCl}$ solution but they were divided by the net, together with that (c) after the leaching of the chalcopyrite concentrate without the promoters as a reference. The peaks of elemental sulfur can not be observed in the pattern ( $b$ ) of the residue of $\mathrm{Fe}_{2} \mathrm{O}_{3}$ powder, while they are clearly observed in the pattern (a) of the residue of chalcopyrite concentrate. Taking the accuracy of XRD into account, it is not always described that no formation of elemental sulfur takes place on the surface of the $\mathrm{Fe}_{2} \mathrm{O}_{3}$ powder. In the leaching of chalcopyrite concentrate with $\mathrm{Fe}_{2} \mathrm{O}_{3}$ powder, the elemental sulfur may be formed mostly in the side of the chalcopyrite concentrate, not the $\mathrm{Fe}_{2} \mathrm{O}_{3}$ powder. No matter how the elemental sulfur layer is formed, it does not seem to be a barrier to further leaching of chalcopyrite concentrate when the $\mathrm{Fe}_{2} \mathrm{O}_{3}$ powder is present. Anyhow, $\mathrm{Fe}_{2} \mathrm{O}_{3}$ powder plays a significant role to assist the dissolution of

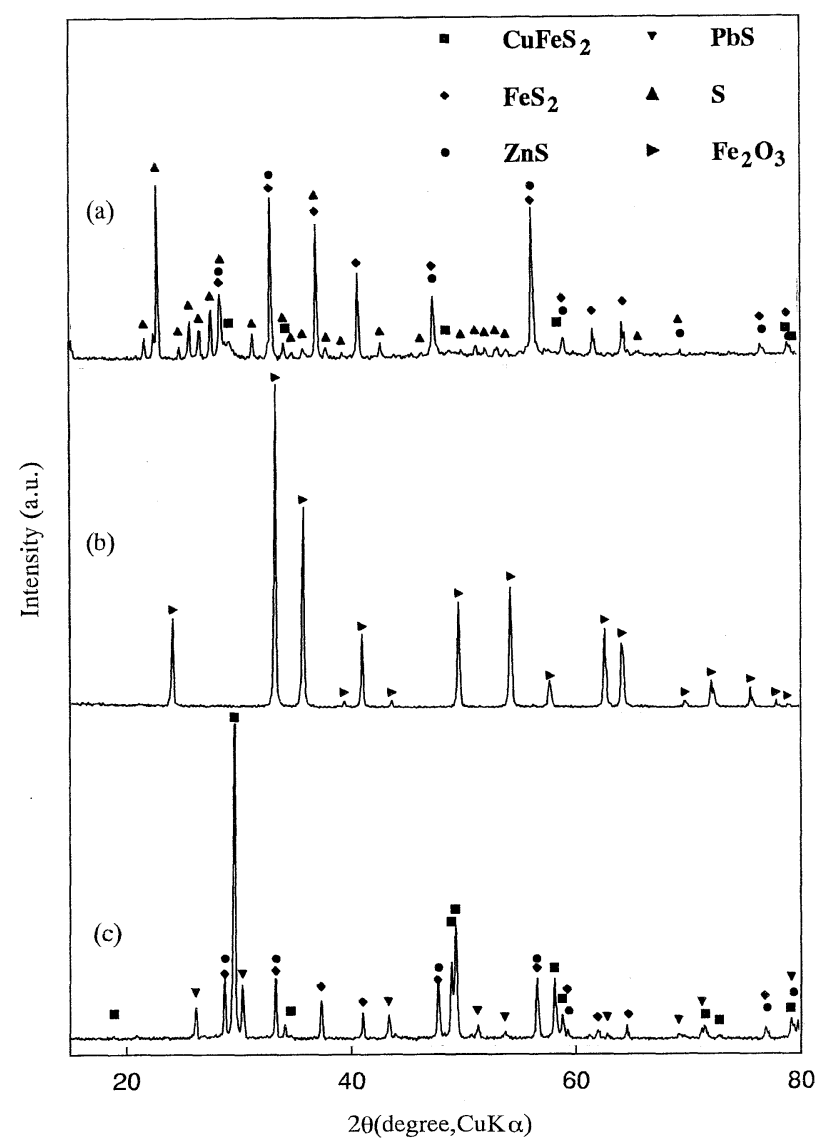

Fig. 3 XRD patterns of the residues after 3-days leaching of the individual samples, together with the residue after the leaching of chalcopyrite concentrate without the promoters as a reference.

(a) chalcopyrite concentrate (with $\mathrm{Fe}_{2} \mathrm{O}_{3}$ powder)

(b) $\mathrm{Fe}_{2} \mathrm{O}_{3}$ powder (with chalcopyrite concentrate)

(c) chalcopyrite concentrate without the promoters chalcopyrite concentrate accompanying with elemental sulfur in the vicinity of the surface of the concentrate. However, no evidence to confirm the reaction phenomena in the chalcopyrite leaching using $\mathrm{HCl}$ solution with $\mathrm{Fe}_{2} \mathrm{O}_{3}$ powder have been provided yet in the present experiment. Though this will be clarified in the future work, at this moment, It is only concluded that $\mathrm{Fe}_{2} \mathrm{O}_{3}$ powder is an effective promoter in the leaching of chalcopyrite concentrate using $\mathrm{HCl}$ solution.

\section{Concluding Remarks}

From the experimental results in the leaching of chalcopyrite concentrate (specific surface area: $3 \mathrm{~m}^{2} / \mathrm{g}$ ) conducted at $333 \mathrm{~K}$ using $0.5 \mathrm{~mol} / \mathrm{dm}^{3} \mathrm{HCl}$ solution, the following concluding remarks could be made:

(1) Presence of $\mathrm{Fe}_{2} \mathrm{O}_{3}$ powder permits to extract about $75 \%$ copper by the 24 hours leaching, while about $65 \%$ copper extraction can be achieved in the leaching with $\mathrm{FeCl}_{3}$ powder. Only about $25 \%$ copper can be extracted by the leaching without any promoters. Therefore, $\mathrm{Fe}_{2} \mathrm{O}_{3}$ could be an effective promoter in the leaching of chalcopyrite concentrate.

(2) High copper extraction can be achieved when much of the elemental sulfur is formed after the leaching. Especially, the presence of $\mathrm{Fe}_{2} \mathrm{O}_{3}$ powder leads to promote the dissolution of chalcopyrite, accompanying with the elemental sulfur precipitates more than $\mathrm{FeCl}_{3}$ powder.

(3) Elemental sulfur may be formed in the vicinity of the chalcopyrite concentrate, not the $\mathrm{Fe}_{2} \mathrm{O}_{3}$ powder when the powder is present. The reaction mechanism in the leaching of the chalcopyrite concentrate with $\mathrm{Fe}_{2} \mathrm{O}_{3}$ powder may be similar to that with $\mathrm{FeCl}_{3}$ powder. However, no evidence to confirm it has been provided yet in this work. Further investigation would be needed.

Acknowledgments The authors wishes to thank Matsumine Mining, Hanaoka Mining Co. Ltd. for kindly supplying the chalcopyrite concentrate sample. One of the authors (E. C. S.) is grateful to the Ministry of Education of Science and Culture of Japan (Monbusho) for financial support provided through the scholarship program.

\section{References}

1) Dutrizac, J. E. : Hydrometallurgy, Vol. 29, p. 1-45, (1974)

2) Majima, H. : Metallurgical and Materials Transactions-B, Vol. 26B, p. $1109-1122, \quad(1995)$

3) Majima, H., Awakura, Y., Hirato, T. and Tanaka, T. : Can. Metall. Q., Vol. 24, p. 283-291, (1985)

4) Hirato, T., Kinoshita, M., Awakura, Y. and Majima, H. : Metall. Trans. B, Vol. 17B, p. 19-28, (1986)

5) Hirato, T., Majima, H. and Awakura, Y. : Metall. Trans. B, Vol. 18B, p. $31-39,(1987)$

6) Hirato, T., Majima, H. and Awakura, Y. : Metall. Trans. B, Vol. 18B, p. $489-496$, (1987)

7) Haver, F. P., Baker, R. D. and Wong, M. M. : "Improvements in Ferric Chloride Leaching of Chalcopyrite Concentrate", U. S. Bur. Mines R. I. 8007, (1975)

8) Cruz Sanchez, E., Umetsu, Y. and Saito, F. : J. Chem. Eng. Japan, Vol. 29 , p. $714-716$, (1996) 
有効浸出助剂としてのへマタイト粉を用いた黄銅鉱の酸浸出

\section{Ezequiel Cruz Sanchez ${ }^{1}$ 梅 津 良 昭 $^{2}$ 齋 藤 文 良 $^{2}$}

$0.5 \mathrm{~mol} / \mathrm{dm}^{3}$ の塩酸を用い, $333 \mathrm{~K}$ の温度でへマタイトならび に塩化第 2 鉄をそれぞれ浸出助剤として比表面積 $3 \mathrm{~m}^{2} / \mathrm{g}$ の黄銅 鉱から銅の浸出実験を行った。へマタイトを用いた浸出実験では, 黄銅鉱を 24 時間浸出した場合, 銅収率が約 $75 \%$ となるのに対 して，塩化第 2 鉄では $65 \%$ となる。へマタイトを用いた場合の 銅収率は, 浸出助剤無しの場合の約 2 倍かそれ以上となる。浸出
後の残査に硫黄が析出するとき高い銅浸出が達成される。特に, ヘマタイトを用いる方が塩化第 2 鉄を用いるよりも硫黄析出が多 い。したがって, ヘマタイトは黄銅鉱の塩酸浸出において効果的 助剤といえる。

1. 東北大学素材工学研究所研究留学生

2. 正会員 工博 東北大学教授 素材工学研究所

キーワード：黄銅鉣，へマタイト，塩化第 2 鉄, 酸漫出, 硫黄, 銅抽出 